\title{
Collection Development Policies for the 21 st Century Academic Library: Creating a New Model
}

\author{
Steve Alleman, Head of Collections, University of Missouri-Kansas City \\ Daniel C. Mack, Interim Director, Collection Management \& Special Collections, University of Maryland
}

The Charleston Conference: 8 November 2013; Charleston, SC

No one denies the need for collection development policies. Librarians seem to agree that an upto-date collection policy is both a good vehicle for strategizing collection priorities as well as a tool for answering those who might question the library's collection decisions. However, there is very little official guidance for those who are charged with devising or revising their institution's collection policy. The second and latest edition of the Guide for Written Collection Policy Statements, published by ALCTS (Collection Management and Development Guides \#7, Joanne S. Anderson, ed.) dates from 1996, which is too old to be of use to librarians struggling with the challenges of moving to digital collections.

ALA's Reference \& User Services Association has a Standards \& Guidelines committee (http://www.ala.org/rusa/contact/rosters/rusa/rus-sag) and a procedure (http://www.ala.org/rusa/about/policies/developingguidelines/4developingguidelines) for developing guidelines for use by practitioners (http://www.ala.org/rusa/resources/guidelines). The Collection Development and Evaluation Section (CODES) of RUSA has established a task force to develop guidelines for collection development policies. However, when this task force began to outline its approach, they discovered that the traditional approach, which not only contains prescriptions related to budget allocations, formats, weeding, and so forth, but which also devoted much of its effort to detailed information about each academic department, ignored many of the challenges of $21^{\text {st }}$ century collection development.

New trends in academic publishing, university curricula, and the $21^{\text {st }}$-century research enterprise require that libraries rethink collection development policies. These trends include an ever-rising demand for digital access to content via a range of platforms and devices, the increasing internationalization and interdisciplinarity of the academy, the need for policies to address values such as diversity and sustainability, and the trend for academic institutions to see library facilities as prime real estate that could serve a higher purpose than merely being a warehouse for print materials that see declining use. In addition to addressing the traditional areas of subject scope and depth, formats, languages and so on, collection development policies in academic libraries should consider how and where to address these points most appropriately.

When creating collection development policies, libraries now need to keep in mind a number of new factors for these policies to address. Content factors include diversity, interdisciplinarity, global issues, diversity, Big Science, and digital humanities. In addition, policies may need to cover publishing and delivery issues such as demand/patron driven acquisition, access versus ownership, and open access. Technical factors are also increasingly important to collection development decisions. Policies might therefore need to address data curation, texts and data mining, research data and born-digital content. Finally, libraries should consider whether it might be appropriate for their collection policies to address space issues, collection assessment, and partnerships with consortia and other collaborative collection development endeavors. 